\title{
Is Street Art a Crime? An Attempt at Examining Street Art Using Criminology
}

\author{
Zeynep Alpaslan \\ Department of Sociology, Hacettepe University, Ankara, Turkey \\ Email: z_alpaslan@hacettepe.edu.tr
}

Received February $1^{\text {st }}, 2012$; revised February $29^{\text {th }}, 2012$; accepted March $13^{\text {th }}, 2012$

\begin{abstract}
A clear and basic definition is the fundamental element in understanding, thus explaining any social scientific concept. Street art is a social phenomenon, characterized by its illegal nature, which social scientists from several subjects have increasingly been examining, interpreting and discussing for the past 50 years. Even though the concept itself has been defined much more clearly over the years, its standing concerning whether it is a crime or form of art is still a borderline issue. This paper attempts to first try to define street art under a type of crime, then examine it using criminological perspective, with criminological and deviance theories in order to understand and explain it better using an example, the KÜF Project from Ankara Turkey.
\end{abstract}

Keywords: Street Art; Definition; Criminology; Crime Theory; KÜF Project

\section{Introduction}

Art, in the general sense, is the process and/or product of deliberately arranging elements in a way that appeals to the senses and/or emotions. Street Art is a form of subcultural activity that is defined as unsanctioned visual art developed and/or practiced in public spaces. This form of art has generally been seen as a post graffiti writing movement and is often characterized by its illegal nature (Hundertmark, 2003). Even though street art carries a much different meaning from its predecessor traditional graffiti artwork, it does include modern graffiti, art intervention, flash mobbing, guerrilla art, sculpture, stencil graffiti, sticker art, street poster art and wheatpasting, street installations and video projection. Typically, the term is used to distinguish contemporary public-space artwork from territorial graffiti, vandalism, and corporate art. John Fekner defines street art as "all art on the street that's not graffiti" (Lewisohn, 2008).

Street art is a powerful platform for reaching the public due to its visual advantages. Its philosophy includes a strong sense of activism and subversion. The universal theme in most, if not all, is "reclaiming the city" and adapting visual artwork into a format which utilizes public space, allowing its artist, who may otherwise feel disenfranchised, to reach a much broader audience than traditional artwork and/or galleries would allow.

"For the street artists, the medium is all forms of public expression and the message is resistance to the uniformity of the city and all that it embodies. This idea of resistance to the city is not only resistance to the visual landscape of the urban environment, but also to the revision of what it stands for and who stands for it." Justin ARMSTRONG (Armstrong, 2005)

When the need for artistic expression and free speech created by oppression, regardless of why it is created, is not possible, individuals who wish to communicate their emotions and ideas seek alternative means of expression and street art acts as a readily available vehicle for those who chose to benefit from what it has to offer. The street artists, who use the technologies of the modern time to claim space, communicate ideas, and express social and/or political views, have motivations and objectives as varied as the artists themselves. Yet there is a constantly looming threat of facing consequences for displaying their art. For this reason many of them choose to protect their identities and reputation by remaining anonymous. With the commercialization of street art, in most cases, even with legally exhibited art, the artists tend to choose anonymity.

\section{Street Art: Around the World and in Turkey}

There are some key locations around the world that are considered as source and inspiration for street art culture in general.

In East Europe, most post communist countries have a very vibrant street art culture. In the North Norway, Stavanger is host to the annual Nuart Festival; one of Europe's leading events dedicated to promoting street art. In the West England, London is one of the most pro-graffiti cities in the world. Ironically, it is also one of the cities where street art is officially condemned and heavily punished by law. Mostly because of Banksy's success, Bristol is part of a vibrant street art scene too. On the other side of the ocean, in North America USA, New York City is considered the home of street art and in South America Brazil, São Paulo is another city viewed as one of the capitals of street art. While Australia is home to one of the worlds most active and diverse street art cultures in Melbourne, Asia has yet to catch up on the hype. As for the Middle East, street art is slowly emerging; Iranian artist Alone's has been interviewed by Tokyo-based design magazine PingMag about his works on Tehran walls (Uleshka, 2007); The Israeli West Bank barrier has become a site for street art, reminiscent in this sense of the Berlin Wall; Turkey has a growing number of local artists, while many foreign artists also exhibit their works in İstanbul.

"The street art works that are seen especially in İstanbul, 


\section{Z. ALPASLAN}

increase day by day. Due to the fact that having many touristic features, it is possible to see the pieces of many Turkish and foreign artists around Taksim and its environs."

Tunc Dindas (Dindas, 2009)

\section{If Street Art Is a Crime ... Which Type of Crime Is It?}

Modern graffiti is essentially illegal, because it has not been accepted by society (Phillips, 1999). Some researchers suggested that authorities have criminalized street art by manipulating public opinions through the media (Ferrell, 1996). Joe Austin argues that the Mass Transit Authorities use their actions against street artists to divert public attention away from problems happening in the cities instead of legalizing it and repurposing the use of tax money somewhere else (Austin, 2001). Street artists, who mostly are taxpayers themselves, argue that they too have ownership over public spaces that have been unfairly taken over by advertisers (Times, 1971). Ironically, street art, which is considered illegal, gains permission to be displayed when endorsed by corporations (Niccolai, 2001). This reveals a double standard and indicates that certain groups in society enjoy privileges when deciding what is art or crime (Dickson, 2008).

Judgments such as "consensus", "harm", "injury", "offender", and "victim" do not have clear, unequivocal definitions and are always informed by contestable, epistemological, moral, and political assumptions (De Haan, 1990). But for the sake of argument, presuming that street art is actually a form of crime, which can cause "harm", and the street artist is a criminal, an "offender" that offends "victim"s, it should be possible to define it under one of the predefined and widely accepted crime types such as: Organized, Corporate, State, State-Corporate, WhiteCollar, Blue-Collar, Political, Public-Order Crimes or Juvenile Delinquency.

\section{Street Art ... An Organized Crime?}

Organized crime or criminal organizations are national, local and/or transnational groupings of highly centralized enterprises, run by criminals engaging in illegal activity mostly for the purpose of monetary profit. Street artists may work on their own or they may work in groups. Those who chose to act as a whole or as a group instead of acting as individuals may even be disciplined enough to be considered organized. Yet since the basic, primary motivation is neither financial gain, nor is it causing damage in a destructive or ill intentioned manner, as terrorist organizations, can street art still be considered a kind of organized crime?

\section{Street Art ... A Corporate Crime?}

Corporate crime refers to crimes committed either by a corporation, by individuals acting on behalf of a corporation or other business entities. Just by this general description, it is safe to say that it has nothing to do with street art.

\section{Street Art ... A State Crime?}

State crime is activity or failures to act that break the state's own criminal law or public international law. This said, the only way street art could be categorized as a state crime would be if in fact the State itself were to use street art as a mean to break its own criminal law or public international law. Unless this is the situation, it could be argued that some of the actions of the State such as banning street art or punishing street artists could be considered a violation or oppression of personal freedom, freedom of thought and thus could be, in a way, a state crime itself.

\section{Street Art ... A State-Corporate Crime?}

State-corporate crime refers to crimes that result from public-private partnership and inherent distorted relations of the state and the policies and practices of commercial corporations surfacing as budget-bonus crime. Again, it is safe to say this topic has nothing to do with street art.

\section{Street Art ... A White-Collar Crime?}

White-collar crime is a financially motivated, economic, nonviolent crime committed for illegal monetary gain. Sutherland (1939) defines white-collar crime as a crime committed by a person of respectability and high social status in the course of his occupation (HG Legal Directories, 2012). Street art is nonviolent, but at this point it is safe to say that even though there has been examples of street artists who have made financial profit by doing commercial work or exhibitions in galleries, street art's basic motivation is not an economic one and as such it would not count as a white-collar crime.

\section{Street Art ... A Blue-Collar Crime?}

Blue-collar crime is any crime committed by an individual from a lower social class as opposed to white-collar crime which is associated with crime committed by individuals of a higher social class and blue-collar crimes are crimes that happen on the streets everyday that can include, but are not limited to: Kidnapping, Rape, Shoplifting or Vandalism.

Vandalism is generally defined as ruthless destruction or spoiling of anything beautiful or venerable (Oxford English Dictionary, 2008). It covers criminal damage towards any property without permission of the owner. The definitions of vandalism leave loop holes for what street art can be considered. For example, an esthetically pleasing design done on a blank or boring surface would not be the destruction or spoiling of anything beautiful or venerable. Neither would street art done on a property which did not belong to one individual, but considered public space. On the contrary, it could improve the urban space.

It is accepted that private citizens commit vandalism when they willfully damage or deface the property of others or the commons. Yet again, the matter comes down to one crucial point: the definition of damaging. If it is done in an artistic nature, even though carried out illegally or without the property owner's permission, can it not be that the final product is actually improving instead of damaging? And if so, would it still be considered vandalism?

Some people become cops because they want to make the world a better place. Some people become vandals because they want to make the world a better looking place Bansky (Bansky, 2005)

\section{Street Art ... A Juvenile Delinquency?}

Juvenile delinquency, also known as youth crime, is participation in illegal behavior by minors who fall under a statutory 


\section{Z. ALPASLAN}

age limit (Siegel \& Welsh, 2011) For many reasons, and with many examples, it is possible to categorize street art under this heading, yet there is one crucial point that again makes this effort fruitless: the fact that even though there are many under aged street artists, most of them are of age. In Australia many state governments have banned the sale or possession of spray paint to those under the age of 18 (age of majority). In New Zealand, a new legislation adopted in 2008 included a ban on the sale of paint spray cans to persons under 18 .

\section{Street Art ... A Political Crime?}

States define any behavior perceived as a threat, real or imagined, to the state's survival including violent and/or nonviolent oppositional crimes, as political crimes. As a result there is a possibility that a conduct, which would normally not be considered a crime, to be criminalized at the convenience of the group holding power. The morality of a law, which simply criminalizes ordinary political dissent, is questionable. In some situations art does present dissent with current regimes, and/or political situations, and this may be deemed threatening by the group holding power. In other situations the mere presence of street art may be considered a threat due to the understanding that monitoring and maintaining urban environments in a wellordered condition, meaning free of street art, may stop further street art or as the Broken Window Theory (Wilson \& Kelling, 1984) put's it—vandalism, as well as an escalation into more serious crime. Yet, all this raises another important question: Is it not possible to think that all art with political dissent and all artists who create them could be offensive to the State at one point or the other, regardless of whether or not they actually do pose a threat? Would this necessarily mean that the artist is a criminal and that what they have created is a crime?

\section{Street Art ... A Public-Order Crime}

Public-Order Crime is defined by as crime which involves acts that interfere with the operations of society and the ability of people to function efficiently (Siegel, 2006), simply meaning it is behavior that has been labeled criminal because it is contrary to shared norms, social values, and customs. This type of crime includes consensual crime, victimless vice, and victimless crime. It asserts the need to use the law to maintain order both in the legal and moral sense. Yet, in the modern society the moral standards, have a tendency to change over time with every new revelation whether in the area of science, technique or even fashion-modern society's moral standards evolve very fast. So is it not true to think that what may now be seen as one thing may very well be perceived very differently in the near future? Downloading free music from the internet was not always considered a crime; it is still not a defined crime with consequences in some countries-yet, there are measures that are being taken in order to make it illegal, on the grounds that it is in fact a kind of theft. In 1916 Margaret Sanger, who founded the first birth control clinic in New York City US, was accused of distributing obscene material and violating public morals yet now, since the information about birth control is no longer considered obscene in the US, if one were to open such a clinic there, they would not be considered violating any public morals. On the contrary, they would be considered doing a positive service to young women who are not mentally, emotionally and/or financially ready to have a baby. Even if one were not to believe in the theory of evolution, they could appreciate the fact that change is a natural part of existence and moral values are subject to change just as much as anything and everything else. Then, is it wrong to presume that, just as there is difference between what was considered a crime in the past and what is considered a crime now, there will be a difference between what is considered a crime now and what will be considered a crime in the future?

Despite what they say graffiti is not the lowest form of art. Although you might have to creep about at night and lie to your mom it's actually one of the more honest art forms available. There's no elitism or hype, it exhibits on the best walls a town has to offer and nobody is put off the price of admission. A wall has always been the best place to publish your work. The people who run our cities don't understand it (street art) because they think nothing has the right to exist unless it makes a profit, which makes their opinion worthless.

Bansky (Bansky, 2005)

\section{Explaining Street Art Using Criminological Theory}

Even though street art may not fit into any one crime definition, it may be possible to examine it from a criminological point of view using the predefined and widely accepted Criminological and Deviance Theories such as: Differential Association, Labeling, Neutralization, Rational Choice, Social Control, Social Disorganization, Social Learning, Strain, Subcultural and Criminal Triad Theory.

\section{Street Art vs. Differential Association}

Differential Association Theory (Sutherland, 1974) is a theory proposing that through interaction with others, individuals learn the attitudes, techniques, motives and values for criminal behavior. It focuses on the how's, but does not concern itself with the reasons behind the why's. Through interaction with other street artists or street art enthusiasts, individuals learn the attitudes, techniques, motives and values for street art too. Yet in order to understand and examine street art and its artist better, understanding the answer to the why's would be essentially more important than understanding the answers to the how's.

\section{Street Art vs. Labeling Theory}

French sociologist Durkheim states that crime is not so much a violation of a penal code as it is an act that outrages society and he was the first to suggest that deviant labeling satisfies that function and satisfies society's need to control the behavior. Labeling Theory holds hypothesizes that the labels applied to individuals influence their behavior, particularly the application of negative or stigmatizing labels promote deviant behavior, becoming a self-fulfilling prophecy. Most street artists tend to choose anonymity and use names other than their own real names. Consequently the label does not have as much gravity as it would and the gravity it does have may not be perceived as expected, at least not by the artists themselves. "Vandal" may be a negative label, but since most street artists take pride in being seen as deviant from norms - as artists, the label's deterrent quality may turn into a motivational one. Just as they do not want to live in urban spaces full of the same and boring structures, neither do they want to be another brick in the wall- same as everyone else. 


\section{Z. ALPASLAN}

\section{Street Art vs. Neutralization Theory}

The Neutralization Theory explains how deviants justify their deviant behaviors by providing alternative definitions of their actions and by providing explanations, to themselves and others, for the lack of guilt for actions in particular situations. Amongst the 5 types of neutralization, Denial of Responsibility (the deviant believes $\mathrm{s}$ /he was helplessly propelled into the deviance, and that under the same circumstances, any other person would resort to similar actions) could be the only type that does not seem fitting to street artists. Street artist may be in Denial of Injury (the deviant believes that the action caused no harm to other individuals or to the society, and thus the deviance is not morally wrong.), Denial of The Victim (the deviant believes that individuals on the receiving end of the deviance were deserving of the results due to the victim's lack of virtue or morals), Condemnation of The Condemners (the deviant believes enforcement figures or victims have the tendency to be equally deviant or otherwise corrupt, and as a result, are hypocrites to stand against) or Appeal to Higher Loyalties (the deviant believes that there are loyalties and values that go beyond the confines of the law; morality, friendships, income, or traditions may be more important to the deviant than legal boundaries). Whether or not they are right about these arguments are some of the core reasons behind street arts legality polemic.

\section{Street Art vs. Rational Choice Theory}

The Rational Choice Theory adopts an idea that man is a reasoning actor who weighs means and ends, costs and benefits, and makes a rational choice. The street artist does weight the means and ends, they pay for it financially, physically and emotionally, expecting little if any benefits (due to choosing anonymity) and make a rational choice to proceed. Routine Activity Theory (Cohen \& Felson, 1979) is a sub-field of rational choice theory in criminology and proposes that crime does not need hardened offenders, super-predators, convicted felons or wicked people, it is normal and depends on the opportunities available. Simply put, if there is an available and suitable target, motivated offender and no authority figure to prevent the crime from happening - it will happen. Consequently, the three elements required for creating street art are the same.

\section{Street Art vs. Social Control Theory}

Social Control Theory proposes that exploiting the process of socialization and social learning builds self-control and reduces the inclination to indulge in behavior recognized as antisocial. Even though this theory may be very much true for the majority, an artist is not quite part of the majority. If anything, an artist is someone who has a slightly different and/or more accurate perception of the world surrounding us, their feelings and/or ideas, and who is not afraid to share this perception with the rest of humanity. This could explain why street artists consistently carry on indulging in behavior recognized as antisocial.

\section{Street Art vs. Social Disorganization Theory}

The Social Disorganization Theory links high crime rates to neighborhood ecological characteristics and this, in the sense that it would link high street art rates to neighborhood ecological characteristics, would make sense in understanding street art better. It would be much more probable for youths from certain neighborhoods to be participants in a subculture in which street art was, even if not approved per say still, acceptable and that understanding was acquired in a social and cultural setting through a process of interaction.

\section{Street Art vs. Social Learning Theory}

Social Learning Theory explains deviancy by combining variables which encouraged delinquency with variables that discouraged delinquency (Burgess \& Akers, 1966). Simply put, according to this theory two qualities shape behavior: punishment and reinforcement. Since social learning theory is a revised version of Sutherland's social disorganization theory, by including the idea of reinforcement and applying the principles of operant psychology (Pfohl, 1994), it is natural to find that it could help in understanding street art better just as well.

\section{Street Art vs. Strain Theory}

Strain Theory states that social structures within society may encourage citizens to commit crime. The gap between expectations and actual achievements come from personal goals and some of those goals will never be realized because of unavoidable circumstances including both inherent weaknesses and opportunities blocked by others. The difference between the view of what a person believes the outcome should be and what actually results increases personal disappointment and frustration. Taking this into consideration, it may be thought; social structures within society may encourage citizens to take part in street art, obviously not for material acquisition, but maybe for social satisfaction. For example: An educated and socially aware person may have an opinion they strongly believe in and they may want to share it, yet not have the necessary tools to do so due to circumstances outside of themselves. The disappointment and frustration created by this may be the most logical explanation to the existence and necessity of street art in today's modern societies. In a way, alternative to the belief that street art is provocative, it may even be the relief valve.

\section{Street Art vs. Subcultural Theory}

The Subcultural Theory is a set of theories arguing that certain groups or subcultures in society have values and attitudes that are conducive to crime and violence. While street artist could very well be a certain group or subculture in society with values and attitudes that are different than the widely accepted social norms, this would not mean that their values and attitudes are conducive to crime and violence. If anything, they chose to be non-violent and express their ideas and feelings using creative and artistic outlets. This theory may stay on the how side more than the why side concerning street art and artists.

\section{Street Art vs. Criminal Triad Theory}

Criminal Triad Theory (Harmening, 2010) is a relatively new theory of criminality that looks at the interplay of three psychosocial developmental processes (attachment, moral development, and identity-formation) in the development of a person's internal deterrence system during adolescence. Taking into account that street artists are as varied as their motivations and objectives, it would be a premature attempt to try and examine street art from this point of view without a generalized street artist psyche model — which may be impossible to achieve at this point in time. 


\section{Z. ALPASLAN}

\section{KÜF Project: An Example from Turkey}

Sarcastic and ironical humor, as way of light hearted criticism of social and/or political issues, is a very deep rooted part of Turkish culture. These roots rest on a long tradition of "Orta Oyunu", the shadow play also known as "Karagoz \& Hacivat", and the caricature culture which have all been part of the society for a long time. It may be argued that street art is now on its way to gradually become accepted as one of them, but with a modern twist.

A group from Ankara (Turkey) KÜF Project ${ }^{1}$, which first got public recondition for changing the road sign leading to G. O. Pasa (a high class district in Ankara, capital of Turkey) into "Tosun Pasa" (a Turkish comedy movie title and it's lead male's name) about two years ago, used street art in a humorous way. Soon after, they transformed Cinnah Caddesi (the main avenue of the capital) into a globally popular Pac-Man themed creation ${ }^{3}$. Just as they were about to "strike" again, the "Mavi Marmara" incident took place and both political and social tensions ran high both in the country and the region ${ }^{4}$. The group canceled their ready plans and spontaneously came up with another, one they deemed more appropriate to how they felt and thought the people would need. In a limited amount of time, they transformed road signs into Peace Signs using stick$\mathrm{ers}^{5}$. After this incident, they continued the light hearted humor about everything and anything they saw fit including the news of the National football team not qualifying into the World $\mathrm{Cup}^{6}$. As their fame grew so did there sphere of influence and "Sigara!" was their next work. In February 2011, they became famous throughout the country overnight with "BUYUKSEHIR KUCUK 1 TL" 8 . They had installed a urinal at the entrance of a major underpass of Ankara, over what they saw as the ugly tiles that turned the countries capital into a giant bathroom. At this point, they had tapped into something much more than just light hearted sarcasm, irony and humor - they had arrived at the true essence of street art:

"While the idea of carrying art to the streets has been a breakthrough and been accepted by the societies all over the world, this has not been the case in Turkey. What people see when they go out where we live is just buildings, pavements, signposts, roads and street lights. Not only does this grayness move people away from visual intelligence, it also creates a monotonous perspective in human mind. Within this pattern, people who use the streets to commute only look at their steps. KÜF is to destroy this monotony. It is to make people look around and be aware. It is a riot. It is neither the representative of a company, organization or political party, nor is apolitical. It is a manifestation formed by the accumulation of the

\footnotetext{
${ }^{1}$ http://www.behance.net/kufproject, http://be.net/kufproject (accessed January 2012).

${ }^{2}$ Making of "Tosun Pasa", shot and edited by Küf Project.

http://vimeo. com/10951255 (accessed January 2012).

${ }^{3}$ Making of "Pac-Man", shot and edited by Küf Project.

http://vimeo.com/- 11195391 (accessed January 2012).

${ }^{4}$ MV Mavi Marmara. http://en.wikipedia.org/wiki/MV_Mavi_Marmara (accessed January 2012).

${ }^{5}$ Making of "Peace Sign", shot and edited by Küf Project.

http://vimeo. com/12246016 (accessed January 2012).

${ }^{6}$ Making of "It's The Football", shot and edited by Küf Project.

http://vi- meo.com/13234739 (accessed January 2012).

7“'Sigara!", shot and edited by Küf Project. http://vimeo.com/17697765.

${ }^{8}$ Making of "BUYUKSEHIR KUCUK 1 TL", shot and edited by Küf Project. http://vimeo.com/20280613 (accessed January 2012).
}

ideas and skills of individuals. Its aim is not polluting the streets, which is the setting for actions, but to color it by revealing the dormant energy.

\section{KÜF MANIFESTATION"9}

After "BUYUKSEHIR KUCUK 1 TL", they started "Ben Sosyal Alkoligim Sevim!!!" (a famous line from a once popular TV series shown for over 10 years, translating to "I Am A Social Alcoholic Sevim!!!"-Sevim refers to the name of the wife of Cemil, the character who uses the line) and displayed their works in both Ankara and Istanbul. The last project they have done has been done about a month ago - in Konya, one of Turkey's more conservative cities. The "I [HEART] KoNYa"" stencil was done on a wall close to the Mevlana Museum, with a Whirling Dervish holding a spray can of paint and seemingly writing the slogan while whirling. While the stencil, as a whole, has the air of Middle Eastern style, it was actually structured over a very well known and popular western logo: the "I [HEART] NY" logo.

After almost two years, the group members still prefer to remain anonymous for obvious reasons-Street art is illegal in Turkey, and thus they are considered criminals.

\section{Are They Really Criminals?}

Even if one knew nothing of KÜF Project, just by reading the Manifestation they would, could and should get a general idea about the who, what, why, where, when and how's behind what they are trying to accomplish. Using this manifestation, and the different criminological and deviance theories gone over in the previous chapter:

- From a neutralization theory point of view, one could state that they are deviants who are justifying their behaviors by providing alternative definitions of their actions and explanations to themselves and others, for the lack of guilt for actions in particular situations. Actually one could state that just in this one paragraph they are exhibiting at least 2 out of 5 neutralizations.

- From a rational choice theory point of view, one could state that they have weighted the means and ends, costs and benefits, and made a rational choice to proceed. Similarly, when reading with a routine activity theory point of view, one could state that they are openly sharing that if and when they find available and suitable targets they are motivated to take action.

- From a strain theory point of view, they are obviously disappointed and frustrated by the urban space that surrounds them and its conditions, and are announcing very clearly their intentions of creating a change.

If it is possible to in fact speculate and/or understand KÜF Project using some criminological and deviance theories as seen in the example above, then maybe it is possible to place their projects under crime types as well.

It is safe to say, none of the street art KÜF has produced can be categorized as Organized, Corporate, State, State-Corporate or White-Collar Crime. Actually "Sigara!", which was more of a stop motion film made with cigarettes, does not even count as crime. As for the rest of the produced street art:

\footnotetext{
${ }^{9}$ KÜF Project Manifestation. http://www.behance.net/kufproject (accessed January 2012).

${ }^{10}$ Making of "I(HEART) KoNYa", shot and edited by Küf Project. http://vimeo.com/33651733 (accessed January 2012).
} 


\section{Z. ALPASLAN}

- Even though none of them were "a ruthless destruction or spoiling of anything beautiful or venerable", due to the fact that all of them (except for "Sigara!") changed the urban space without permission - thus illegally, they could all be considered as vandalism, a blue-color crime.

- Members of KÜF are not only anonymous; they are also quite private about how many people they are, their ages, sexes, educational and/or professional statuses etc, so it is hard to say whether or not their projects can be classified as juvenile delinquency - though taking into consideration their interviews with news papers and project footages they share over the internet, it does seem that even if not all of them, at least most of them may be over the legal age of 18 .

- Except for "BUYUKSEHIR KUCUK 1 TL" none of the produced street art can count as political crime. "BUYUKSEHIR KUCUK 1 TL", which was an obvious and direct political dissent, was politically-motivated, yet it was not a threat to the State or political regime, it was a critique of the metropolitan mayor and his urban design policies.

- "Tosun Pasa" and "It's The Football" both included minor changes being made to traffic signs, which could, in a sense, involve an act that interferes with the operations of society and the ability of people to function efficiently, making them public-order crimes. But in all honesty, unless the society operating or the people functioning referred to were strangers to this specific urban space (Ankara), it would be very hard for them to lose efficiency due to these minor interferences.

Street art may not be legal, but it seems as though neither is it illegal. If it is not illegal, than there is no crime, meaning there is no criminal in this example.

\section{Conclusion}

Presuming that street art could be a form of crime which could cause "harm", while the street artist would be a type of criminal, who would be an "offender" and there would be "victim"s to these offences, it should have been possible to define it under a type of crime. It was obvious that street art could not be categorized as Organized, Corporate, State, State-Corporate or White-Collar Crimes, yet it was possible to squeeze it into fitting Blue-Collar, Political, Public-Order Crimes and/or Juvenile Delinquency. It seems as though there is just too much subjecttivity concerning what Vandalism is and/or what it means; where the line is drawn between what is ordinary political dissent shared and what is a threat to the State and/or the current regime; what interferes with the operations of society and the ability of people to function efficiently; even the exact age of most street artists.

After trying to establish which type of crime street art would fit properly in and failing, an attempt was made in examining street art using a criminological point of view, with criminological and deviance theories in order to understand and explain it better. This resulted with noting that while some theories such as the labeling and social control theories assumptions and the street art experience were not consistent (even opposite at times), some theories assumptions and the street art experience was consistent. Amongst those consistent, there were theories that are better at gathering information on the how's behind what is happening and would not do much in helping understand the reasons behind what is happening such as the differential association and subcultural theory; while there were theories that could in fact be very helpful in understanding the why's behind what is happening such as especially the strain and neutralization theories.

After going over an example, the KÜF Project from Ankara Turkey with the deductions made in previous chapters, this paper concludes that even though street art may be considered illegal in almost everywhere in the world with only a few circumstantial exceptions, and street artists are viewed as criminals; the fact that street art cannot be classified properly in any of the predefined crime categories raises the question whether it actually is a real crime. Hence, this paper concludes that neither street art is a crime, nor is the street artist a criminal-as is stated in their names, while the former is a form of art, the latter is an artist.

\section{REFERENCES}

Armstrong, J. (2005). The contested gallery: Street art, ethnography and the search for urban understandings. AmeriQuests, 2.

Austin, J. (2001). Taking the train. New York: Columbia University Press. Bansky (2005). Wall and piece. London: Random House.

Burgess, R., \& Akers, R. (1966) A differential association-reinforcement theory of criminal behavior. Social Problems, 14, 128-147. doi:10.1525/sp.1966.14.2.03a00020

Cohen, L., \& Felson, M. (1979). Social change and crime rate trends: a routine activity approach. American Sociological Review, 44, 588608. doi:/10.2307/2094589

De Haan, W. (1990). The politics of redress: Crime, punishment and penal abolition. Boston: Unwin Hyman.

Dickson, M. (2008). The making of space, race and place. Critique of Anthropology, 28, 27-45.

Dindas, T. (2009). Street soul graffiti from Turkey. Martı Matbaacıllk Sanatları.

Ferrell, J. (1996). Crimes of style: Urban graffiti and the politics of criminality. New York: Garland.

Harmening, W. (2010). The criminal triad: Psychosocial development of the criminal personality type. Springfield: Charles C. Thomas.

HG Legal Directories. (2012). White collar crime. URL (last checked January 2012). http://www.hg.org/white-collar-crime.html

Hundertmark, C. (2003). The art of rebellion-World of street art. Corte Madera, CA: Ginko Press Inc.

Lewisohn, C. (2008). Street art: The graffiti revolution. London: Tate Museum.

Niccolai, J. (2001). IBM's graffiti ads run afoul of city officials. URL (last checked January 2012).

http://edition.cnn.com/2001/TECH/industry/04/19/ibm.guerilla.idg/

Oxford English Dictionary. (2008). Oxford University Press. URL (last checked January 2012). http://www.oed.com/

Pfohl, S. J. (1994). Images of deviance and social control: A sociological history. New York: McGraw-Hill.

Phillips, S. A. (1999). Wallbanin, graffiti and gangs in L.A. Chicago: The University of Chicago Press.

Siegel, L. J. (2006). Criminology: Theories, patterns, \& typologies (9th ed.). Belmont, CA: Wadsworth Publishing.

Siegel, L. J., \& Welsh, B. C. (2011). Juvenile delinquency: The core (4th ed.). Belmont, CA: Wadsworth Publishing Co Inc.

Sutherland, E. H. (1974.) Criminology (9th ed.). Philadelphia: Lippincott.

Times, New York (1971) “Taki 183” spawns pen pals. New York City. URL (last checked January 2012). http://www.ni9e.com/blog_images/taki_183.pdf

Uleshka. (2007). A1one: 1st generation Graffiti in Iran. PingMag, 19. URL (last checked January 2012).

http://pingmag.jp/2007/01/19/a1 one-1 st-generation-graffiti-in-iran/

Wilson, J. Q., \& Kelling, G. L. (1984). Broken windows: The police and neighborhood safety. The Atlantic Online. URL (last checked January 2012).

http://www.forestry.gov.uk/pdf/BrokenWindowTheory.pdf/\$FILE/Br okenWindowTheory.pdf 